\title{
Environmental damage and public health threat caused by cemeteries: a proposal of ideal cemeteries for the growing urban sprawl
}

\author{
Dano ambiental e ameaça à saúde pública por cemitérios: \\ uma proposta de cemitério ideal diante da crescente expansão urbana
}

Alcindo Neckel ${ }^{[0]}$, Carlos Costa ${ }^{[a]}$, Débora Nunes Mario ${ }^{[a]}$, Clarice Elvira Saggin Sabadin ${ }^{[0]}$, Eliane Thaines Bodah ${ }^{[b]}$

\footnotetext{
[a] Faculdade Meridional (IMED), Passo Fundo, RS, Brazil

${ }^{[b]}$ Washington State University, Tacoma, WA, USA
}

\begin{abstract}
Growing urban land development has led to a reduction in the space available for cemeteries and the juxtaposition of residential and cemeterial areas, further raising the polluting potential of the latter. The present case study sought to assess levels of physicochemical and microbiological contamination in the Central Cemetery of Marau (RS/Brazil), and propose vertical cemetery deployment as a way to reduce necroleachate-linked pollution impacts. The following information was collected from 43 additional rural cemeteries: number of tombs, graves, chapels, and small vertical constructions with drawers, state of conservation and cleanliness and total area and perimeter of the cemetery. Eighty professionals of environmentally sustainable urban planning from four countries (20 Brazilians, 20 American, 20 Portuguese and 20 Japanese) were interviewed regarding the 'ideal cemetery'. Various risks of cemetery soil contamination were identified, particularly high amounts of heterotrophic microorganisms, especially fecal coliforms associated with burial sites. In order to avoid contamination risks to environment and population, the mplemention of a vertical model of cemetery is proposed.
\end{abstract}

Keywords: Vertical cemetery. Geoprocessing. Contamination. Necroleachate.

\section{Resumo}

O crescente desenvolvimento territorial urbano tem ocasionado redução de espaços disponíveis para os cemitérios, provocando a justaposição de zonas residenciais e cemiteriais, o que agrava ainda mais o potencial poluidor destes. Este estudo de caso tem como objetivo avaliar os níveis de contaminação físico-química e microbiológica no Cemitério Central de Marau (RS/Brasil) e propor formas para reduzir os impactos de contaminação por necrochorume, por meio de implantação de cemitério vertical. De outros 43 cemitérios,

\footnotetext{
AN is a geographer, Ph.D. in Geography from the Universidade Federal do Rio Grande do Sul (UFRGS), e-mail: alcindo.neckel@imed.edu.br CC is Ph.D. in Plant Science from McGill University, Canada, e-mail: carlos.costa1@gmail.com DNM is a Ph.D. in Pharmaceutical Sciences from the Universidade Federal de Santa Maria (UFSM), e-mail: debora.mario@imed.edu.br CESS is a biologist, Master of Science from the Escola Paulista de Medicina - EPM, Universidade Federal de São Paulo - UNIFESP, e-mail: clarice.saggin@imed.edu.br ETB is a biologist, Ph.D. in Horticulture from Washington State University, United States, e-mail: elianeb@uw.edu
} 
situados em áreas rurais, foram coletadas informações como: número de túmulos, covas, capelas, pequenas construções verticais com gavetas, estado de manutenção e de limpeza, e área total do perímetro cemiterial. Oitenta profissionais da área de planejamento urbano e de meio ambiente de quatro países (20 brasileiros, 20 americanos, 20 portugueses e 20 japoneses) foram entrevistados e opinaram sobre a projeção de um cemitério ideal. Os resultados evidenciam vários riscos de contaminação do solo cemiterial, altas quantidades de microrganismos, principalmente coliformes fecais e totais, bactérias heterotróficas. A implementação de um modelo verticalizado de cemitério é proposta a fim de minimizar os impactos ambientais e evitar riscos de contaminação à população.

Palavras-chave: Cemitério vertical. Geoprocessamento. Contaminação. Necrochorume.

\section{Introduction}

Cities are perceived on the basis of the results of physical and human formations that have integrated the social, economic and environmental diversity (Alnsour, 2016). The fact that cities in many developing countries have the goal of improving the quality of life of the population through efficient urban services focused on infrastructure bring up a challenge because urban growth is very fast and constant (Alnsour, 2016; Colantoni et al., 2016).

According to Alnsour (2016), urban growth is modeled by people's actions and, therefore, the diversity of urban services that society has created throughout its existence cannot be ignored. This society has built and made use of the variety of services to meet their basic needs (Lauwers, 2015; Colantoni et al., 2016). One of these needs is the deposition of dead bodies, for which cemeteries serve, as an important human invention (Lauwers, 2015; Zhang et al., 2016).

Urban growth has steadily advanced on cemeterial areas as a result of population growth. This involves an increase in the number of houses in areas not previously occupied (Lauwers, 2015). This aspect cannot go unnoticed by the town planning department that should consider the importance of developing research in cemeteries, highlighting patterns and processes of urban expansion and the change in contemporary cities from the perspective of contamination by cemeteries that may cause harmful impacts on the environment (Trindade \& Neckel, 2014; Lauwers, 2015; Alnsour, 2016; Colantoni et al., 2016; Zhang et al., 2016).

The current environment reflects the cumulative effect of intense physical changes imposed on the geographic domain by men. Most human beings continue to interact with this domain after death (Jones, 2011).
They are transformed as their bodies decompose after burial in open fields termed cemeteries (Jones, 2011; Curşeu \& Pop-Curşeu, 2011; Marcomini, 2012). In Europe, such sites are demarcated by boundaries and fences to separate them from other types of land use (Simonetti, 2012).

Denser urban populations and the need to expand cities has led areas surrounding urban cemeteries to become more frequently tenanted, which, in turn, decreases the possibility of horizontal expansion of cemeteries (Rubio et al., 2012).

As sites where human matter undergoes changes through the action of biological, physical or chemical agents, cemeteries pose environmental risks for the population due the levels of contaminants released (Marcomini, 2012; Oliveira et al., 2012). Cemeteries represent a source of environmental liability due to their potential to accumulate and release large quantities of contaminants generated by the decomposition of corpses. Effluents can carry microorganisms and heavy metals through the soil to water resources. Since these environments have concentrated potential polluters (i.e., are pollution point sources), populations living close to cemeteries may be exposed to elevated levels of highly harmful contaminants to human health (Oliveira et al., 2012). This is exacerbated by the lack of management and treatment of highly pathogenic effluents released by corpses (necroleachate) during the decomposition process.

The above mentioned issues represent a matter of concern because groundwater can be contaminated by nitrogen $(\mathrm{N})$, phosphorus $(\mathrm{P})$, bacteria and viruses, and this kind of contamination is particularly likely to occur in Brazil due to the typical hot and humid climate and heavy rainfall events. These factors contribute to increasing water percolation in the 
soil, thereby favouring proliferation of pathogenic bacteria (Żychowski, 2012).

Excessive physical - chemical or biological cemeterial soil contamination has been reported in other regions of the world (Geleta et al., 2014; Całkosiński et al., 2015; Killgrove \& Montgomery, 2016). This reinforces the importance of carrying out studies investigating the degree of contamination and attendant risks that cemeteries present to the population. There is a need of building appropriate cemeteries to adequately receive dead bodies and minimize the effects of juxtaposition between residential and cemeterial areas.

In the State of Rio Grande do Sul, Brazil, where the present study was conducted, environmental contamination linked to cemeteries began in indigenous burials sites around 1000 BC (Iriarte et al., 2013). Throughout the centuries, the increase of population and burials has worsened this scenario (Brown, 2013). Nowadays, most cemetery spaces are in their third layer of disposal of dead bodies (Trindade \& Neckel, 2014).

Putrefaction involves several phases; full skeletonization is reached after more than three years (Figure 1) (Swann et al., 2010; Schotsmans et al., 2014; Trindade \& Neckel, 2014). Trindade \& Neckel (2014) mentioned that the level of liquid and solid contaminants released from a corpse is high from 72 hours up to 3 years after death.

From phase I through phase IV, degradation occurs in the inner walls of the body, which liquefies (Pacheco,
2000). However, the release of substances into the environment, attendant upon the decomposing body, starts in phase V through phase VII (Figure 1). In these phases, gases such as hydrogen sulfide, mercaptans, carbon dioxide, methane, ammonia and phosphine are released (Pacheco, 2000; Trindade \& Neckel, 2014; Całkosiński et al., 2015). Authors also indicate that 30 to 40 liters of necroleachate are released into the environment (in the case of the decomposition of an individual of $\sim 70 \mathrm{~kg}$ ). Finally, in the phases IV through VIII, complete skeletonization takes place. This occurs when the body has been buried for more than 3 years and all the soft portions of the body are already decomposed, leaving only bones - the mineral portion (Pacheco, 2000; Swann et al., 2010; Schotsmans et al., 2014; Trindade \& Neckel, 2014).

The increasing overcrowding of cemeteries is a matter of concern due to the increase of contaminant release into the soil from the percolation of necroleachate emanating from decomposing corpses (Pereira et al., 2014; Pretti, 2015). At ambient conditions, the transmission of infectious diseases (hepatitis A and typhoid fever) can reach a radius exceeding $400 \mathrm{~m}$ beyond the cemetery (Pereira et al., 2014; Pretti, 2015) Decomposition results in the production of the volatile diamines known as cadaverine $\left[\mathrm{NH}_{2}\left(\mathrm{NH}_{2}\right)_{5} \mathrm{NH}_{2}\right.$, M.W. $102.178 \mathrm{~g} \mathrm{~mol}^{-1}$, m.p. $11.83^{\circ} \mathrm{C}$, b.p. $\left.179.1^{\circ} \mathrm{C}\right]$ and putrescine $\left[\mathrm{NH}_{2}\left(\mathrm{CH}_{2}\right)_{4} \mathrm{NH}_{2}, \mathrm{M} . \mathrm{W} .88 .152 \mathrm{~g} \mathrm{~mol}^{-1}\right.$, m.p. $27.5^{\circ} \mathrm{C}$, b.p. $158.6^{\circ} \mathrm{C}$ ], which, when degraded, generate $\mathrm{NH}_{4}^{+}$(ionized ammonia or ammonium ion),

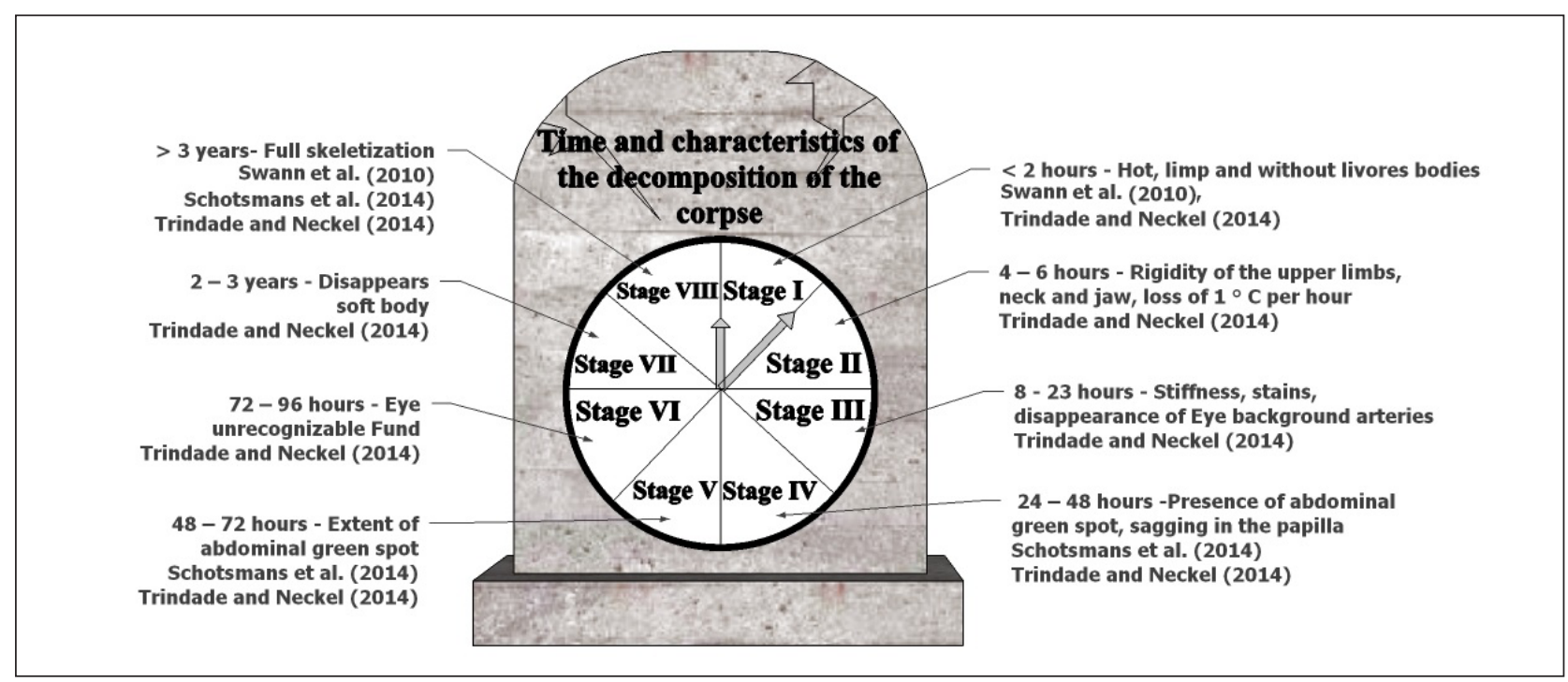

Figure 1 - Stages of decomposition of the human body after death

Source: Adapted from the stages established by Swann et al. (2010), Schotsmans et al. (2014), Trindade \& Neckel (2014). 
nitrite $\left(\mathrm{NO}_{2}^{-}\right)$and nitrate $\left(\mathrm{NO}_{3}^{-}\right)$. At high concentrations, these are highly pollutant and toxic to humans.

In parallel with population growth, contamination generated by cemeteries has continued to increase (Quinn, 2015; Dimakis, 2015; Klaver, 2015). In general, given the size of the area they occupy, urban cemeteries are located in regions of reduced socioeconomic development, and areas economically undervalued. As these areas lack sanitation, they are prone to potential contamination.

According to the analysis of Bennett \& Davies (2015), one solution to reducing environmental contamination generated by cemeteries could be to use a zoning process coupled with analysis of the social and environmental impact involved in administering cemeteries as planned environments. This would enable the treatment of effluents and gases, thereby not exposing the soil to contamination by necroleachate. Vertical cemeteries could prove a viable way of mitigating environmental impacts. Moreover, a skeleton stored in a sconce would not suffer the pressure of the soil weight, and thus remain undamaged (McGowan \& Prangnell, 2015).

The international law for cemeteries in the "Section 5 of the Act of 1903 Ill. Rev. Stat. ch. 21 to. 39 (1951)" considers "[...] graves for the dead, public or private property, as an indispensable human right". Cemeteries, especially in the United States, must be licensed in order to operate, as defined in the $\S 2$ of the Cemetery Care Act, Ill. Rev. Stat. ch. 21 to. 64.1 et seq. (ILCS, 1951), enacted by the $65^{\text {th }}$ General Assembly. In Brazil, laws on how cemeteries should operate are less clear. In turn, in the USA, cemeteries must present annual budget proposals based on legalized investment funds intended for cemetery management, along with graveyard maintenance and improvement (Brown, 2013; Bennett \& Davies, 2015).

At the same time, the National Environment Council (Conama) in Brazil, through the Resolution 335 of April 3, 2003 stipulated that by the end of 2010 all cemeteries must go through an environmental licensing process, requiring compliance with environmental regulations; however, in practice, this did not occur (Brasil, 2003).

Thus, unaware of government resolutions, population began to build houses next to cemeteries (Lauwers, 2015). This housing proximity to cemeteries is a result of population growth that poses the social need to occupy those areas (Lauwers, 2015).
To Lauwers (2015) and Zhang et al. (2016), what awakens a new configuration in the form of urban structure which ignores the care established in the Middle Ages are the cities that should stay away from cemeteries, thus avoiding contamination of the population. Such intense urban growth makes it necessary to imagine future scenarios wheere the number of deaths will increase due to population growth, thus making cemeteries a constant problem for the government (Lauwers, 2015; Zhang et al., 2016).

In order to raise information on the development of ways to reduce the impacts of contaminants originating from urban cemeteries, this study sought to evaluate from an environmental perspective the levels of physical, chemical and microbiological contamination in the Central Cemetery in Marau, RS, Brazil. To this end, a case study conducted on site was designed to evaluate the extent of contamination by necroleachate, and to analyze current and future risks to the environment under a scenario of constant population growth. The implementation of a vertical cemetery model designed to avoid contamination risks to the population is proposed.

\section{Methods}

The extent of physical, chemical and microbiological contamination of the Central Cemetery situated in the city of Marau, Rio Grande do Sul State, northern Brazil $\left(28^{\circ} 26^{\prime} 57^{\prime \prime} \mathrm{S}\right.$ and $52^{\circ} 12^{\prime} 00^{\prime \prime} \mathrm{W}$, altitude of $\left.571 \mathrm{~m}\right)$ was assessed. According to the Brazilian Institute of Geography and Statistics estimates (IBGE, 2014), the

Table 1 - Descriptive statistics of land surface, number of tombs and chapels within the cemeteries of Marau rural areas

\begin{tabular}{cccc}
\hline Statistics & $\begin{array}{c}\text { Surface } \\
\left(\mathbf{m}^{2}\right)\end{array}$ & $\begin{array}{c}\text { Number of } \\
\text { tombs/cemetery }\end{array}$ & $\begin{array}{c}\text { Number of } \\
\text { chapels/cemetery }\end{array}$ \\
\hline Mean & 35,635 & 22.8 & 11.58 \\
Median & 31,700 & 12.0 & 10.50 \\
Standard & 24,167 & 41.0 & 8.43 \\
Deviation & & & \\
Minimum & 400.0 & 1 & 1 \\
Maximum & 96,000 & 261.0 & 32 \\
$\mathrm{n}$ & 43.0 & 41 & 38 \\
\hline
\end{tabular}

Source: Data collected by the authors field (2015). 
city of Marau had a population of 39,693 inhabitants in July 2014 living in an area of $649.30 \mathrm{~km}^{2}$. The city administers a Central Cemetery and 43 further cemeteries located in rural areas of Marau (Table 1).

The following data were collected from each one of the 43 cemeteries in rural areas: number of tombs, graves, chapels, and small vertical constructions with sconces (i.e., mausoleums), maintenance and cleaning protocols, as well as the cemetery's total area and perimeter. For this study, data on contamination were obtained only at the Central Cemetery (encoded as $\mathrm{n}$ o 1 ) because this is the largest cemetery, with a total area of $35.712 \mathrm{~m}^{2}$, and because its higher density of burials (three deep in some areas). In addition, reports of historical events associated with some of these cemeteries were collected with local residents.

We used the Triangular Irregular Network (TIN) method (Firkowski, 2002) to define the sampling location points for microbiological and physicochemical analyses in the central cemetery. This method requires a minimum of three sampling points, but because of the square shape of the site, we worked with four points (A, B, C and D) to allow the inclusion of the largest possible area of the cemetery. Collected data were interpolated using the "Overlay Maps" command of Surfer12 software (Golden Software, 2015).

Soil samples (0.20-0.40 m depth) were collected in triplicate at four locations (points A, B, C, D) in the Central Cemetery (Fiorin, 2007), in accordance with the procedures specified by EMBRAPA (2011). Collected material was packed in plastic bags, stored in coolers and reached the laboratory within 4 hours from collection. Physicochemical analyses of organic carbon, biochemical oxygen demand (BOD) and chemical oxygen demand (COD) followed standard methods (APHA, 2005), considering five days at $20{ }^{\circ} \mathrm{C}$ up to $3 \mathrm{mg} \mathrm{L}^{-1} \mathrm{O}_{2}$. The $\mathrm{pH}$ at $20^{\circ}$ of a $5 \%$ soil suspension $(\mathrm{w} / \mathrm{v})$ was determined by potentiometry (Stutter et al., 2013; Daynes et al., 2013).

For microbiological analyses, suspensions of individual soil subsamples (10 g) were prepared in $90 \mathrm{~mL}$ of sterile water, and each one was housed in a $250 \mathrm{~mL}$ Erlenmeyer flask. A series of one-in-ten dilutions $\left(\frac{1}{10}, \frac{1}{100}\right.$, and $\frac{1}{1000}$, each in triplicate) were prepared from the initial suspension. As a presumptive test for coliforms, a multiple tube technique with inverted Durhan tubes and a lauryl sulfate tryptose broth (LST) medium were employed. Quantification of total coliforms was conducted by transferring the contents of positive tubes into vessels containing brilliant green lactose bile broth $2 \%$ and incubating them in a water bath for $24-48$ hours at $35^{\circ} \mathrm{C}$. Confirmation of fecal coliforms was done by pricking Escherichia coli (EC) broth and incubating in a water bath for 24-48 hours at $45^{\circ} \mathrm{C}$. After noting positive tubes, the most probable number (MPN) was determined using a Hoskins Table. The default count of bacteria identified contamination of samples by heterotrophs. Aliquots $(0.1 \mathrm{~mL})$ from each serial dilution of the original soil suspension were plated on PCA medium (Plate Count Agar) and incubated at $37^{\circ} \mathrm{C}$ for 24 hours and then counted for Colony forming units (CFUs).

Seeking to develop an ideal cemetery design in the face of the Central Cemetery soil's high microbiological contamination, we interviewed 80 Brazilian and foreign researchers of urban planning, architecture and environmental sciences (20 Brazilians, 20 Americans, 20 Portuguese and 20 Japanese). Interviews were based on Stated Preference Method (Ribeiro, 2015), which made it possible to know their preferences about what would be an ideal cemetery in a global perspective.

Participants were randomly chosen from universities in Brazil and in the USA, the Atlantic International University and Washington State University, based on a preliminary analysis of their discipline and under the following criteria: professional experience and qualifications; relevance in scientific circles, as measured by the number of publications in the area of urban planning. Data collected in the interviews were organized in tables and submitted to content analysis method (Bardin, 2011), allowing classification of elements into categories and identification of answers common to multiple respondents.

\section{Current state of the analyzed cemeteries}

As a result of the rural exodus, cemeteries in the rural areas of Marau township, RS, Brazil have low density of burials compared to the Central Cemetery (no 1). No prior notification was made to the ruling authorities or to the administration of individual cemeteries - usually represented by local residents - with regard to new burials or transfers of bodies to other locations. Local resident-administrators see the transfers of bodies as a simple matter dictated by 
the wants of the deceased individual's family rather than a complex process requiring care and planning.

These very old rural cemeteries bear a vast and untapped historical and cultural wealth, and serve as a register of last names of a number of families no longer living in that area. Nearby residents report that the record includes indigenous people who lived there for many years.

The land destined for the burial of the dead in the rural areas are of various sizes; $50 \%$ of them are of up to $31,700 \mathrm{~m}^{2}$ in total area, with an average of $35,635 \mathrm{~m}^{2}$ (Table 1). In these rural areas, there are small family cemeteries on private properties and larger ones for community use in each location. The number of graves and chapels per cemetery reflect the diversity and variation observed in the dimensions of the cemeteries in these areas. There are cemeteries with one tomb and chapel and others with 261 and 32 tombs and chapels, respectively.

Some of the cemeteries investigated were quite important when they were built, in terms of organization, historical and architectural features. This is the case of Tope Cemetery and a private cemetery in the town called Carreta Quebrada. In these places tombs and graves of burials bear family names of traditional descendants of French, Portuguese and other ethnic groups dating from as far back as the nineteenth century. In terms of maintenance and cleaning, the great devotion of families who care for the cemeteries was confirmed: in $78 \%$ of cases, cemetery lands were free of poultry or extraneous vegetation.

Within the cemeteries of Marau township area, 1,542 graves, 994 chapels, 557 pits and 740 sconces were enumerated. It is noteworthy that there were graves with up to five individuals per grave. Among all Marau township cemeteries, the Central Cemetery houses the greatest number of tombs (39.43\%), chapels (55.73\%), pits (11.77\%) and all the sconces. This fact also explains the choice of the Central Cemetery as the object of microbiological, physical and chemical studies.

The Central Cemetery was found to comply with Conama Resolution 335, which states that, from December 2010 onwards (Brasil, 2008), burial works must be done at least five meters away from the cemetery's boundary. However, it was possible to identify necroleachate leakage from the top sconce by observing through a crack in the wall of a mausoleum that recently received a corpse. Because people are not generally aware of this type of problem or the associated health risks, they can inadvertently be exposed to contaminants originating from decomposing bodies that are released into the environment. According to Pereira et al. (2014) and Pretti (2015), leakage of necroleachate through cracks in structures housing caskets can heighten the risk of people getting exposed to microbial contaminants in leachate, which can serve as an infection vector for hepatitis A.

Carelessness on the part of visitors and caretakers with respect to the accumulation of disused materials was noted. In this sense, Article 9 of Conama Resolution 335/03 requires the proper disposal of non-human solid waste resulting from the exhumation of bodies. When materials like open coffins with shroud debris are carelessly exposed, they can serve as potential disease vectors. These problems are rarely addressed in rural areas; the infrequent visits of enforcement agencies only worsens the situation. Thus, it is important to be more vigilant regarding the prevention of these problems.

\section{Central cemetery}

The city of Marau has a centrally-located urban cemetery currently housing 740 individual sconces, 608 tombs, 99 pits and 554 mausoleums. Attempts have been made to adapt it to local population growth.

That the cemetery has 2,001 burial sites of all types set aside for one or two families, many bearing no identification, what hinders the possibility to conduct an accurate survey of those sites. Indeed, the mausoleums have an average of six sconces that are not identified. In order for these figures to be accurate, it would be necessary to conduct a survey of each family that owns a chapel. However, such survey falls outside the purview of this study.

When interviewed, the responsible person for overseeing construction in the Central Cemetery predicted that over thirty mausoleums would be built within the next six months. Given that, according to the Trentin Civil Registry and Notary Office of Marau, RS, an average of 11 deaths and 40 births a month have occurred in Marau between 1995 and 2015 (i.e., 29 person per month of population increase). Thus, serious concerns have been raised regarding the future demographics of the Marau Central Cemetery. Consequently, even ignoring the settlement of migrants 
that come in response to a recent increasing businesses trend and who establish themselves in the area, the coming increase of the death rate looms problematic for any future government (Trindade \& Neckel, 2014; Quinn, 2015; Dimakis, 2015; Klaver, 2015).

\section{Physicochemical and microbiological analyses carried out on the soil of the central cemetery}

In this study, soil samples were collected in loco in the city of Marau's 3.57 ha Central Cemetery, which has a high density of burials - at some locations points it reaches a third burial layer. Laboratory tests of cemetery soil exposed various contamination risks (Table 2), which should be taken as a warning that further research must be undertaken in other cities in Brazil, as well as in other countries. After analysing the soil samples from the four sampling points (A, B, C and D) in Marau's Central Cemetery and averaging the three measured values for each site, values were plotted in Surfer 12 software (Figure 2, 3) by interpolating between the four points.

Soil OC at the sampling points (Table 2, Figure 2) ranged from $7.41 \mathrm{~g} \mathrm{hg}^{-1}$ (C) to $7.75 \mathrm{~g} \mathrm{hg}^{-1}(\mathrm{~A})$, well above the values of $0.7 \mathrm{~g} \mathrm{hg}^{-1}$ and $4.2 \mathrm{~g} \mathrm{hg}^{-1}$ measured in the same cemetery by Tournassat et al. (2011) and Stutter et al. (2013), respectively. Such a high OC level in the soil might interfere with the contamination of the deeper layers of the profile; however, this would also depend on the levels of clay present, i.e., the greater the clay content, the lower the soil's cation exchange capacity (Goren et al., 2011). The large quantity of OC was not unusual because cemeteries are areas of constant decomposition of organic matter (Goren et al., 2011; Daynes et al., 2013; Trindade \& Neckel, 2014).

BOD Soil at the sampling points (Table 2, Figure 3) ranged from $\approx 2.0 \mathrm{mg} \mathrm{L}^{-1}(\mathrm{~A}, \mathrm{~B}, \mathrm{D})$ to $11.03 \mathrm{mg} \mathrm{L}^{-1}$ (C), a value well over the recommended limit of $5 \mathrm{mg} \mathrm{L}^{-1}$. The greater BOD at site $\mathrm{C}$ suggests a higher biodegradability of the cemetery soil at this location (Salles et al., 2010). In contrast to BOD, COD soil was lowest at sampling point $\mathrm{C}\left(3.33 \mathrm{mg} \mathrm{L}^{-1}\right)$ and highest at the other sites $\left(\approx 6.1 \mathrm{mg} \mathrm{L}^{-1}\right)$, indicating that the soil of the Central Cemetery does not present the necessary factors for efficient microbial biodegradative action (Silva \& Malagutti, 2010).

Soil $\mathrm{pH}$ values at the sampling points (Table 2, Figure 2) ranged from 6.20 (C) to 7.27 (A). Although $\mathrm{pH}$ values were close to neutrality, the highest alkalinity occurred at point $\mathrm{C}$, consistent with an inefficiency in OM decomposition (Tournassat et al., 2011; Stutter et al., 2013).

A similar cemetery soil study was carried out by Silva et al. (2008) where soil samples and water from outcrops located in Central Cemetery or in its surroundings were analysed. Another similar study was also carried out by Ueda et al. (2011) who identified and compared microbiota in the cemeteries of São Pedro and Vila Nova Cachoeirinha.

Soil fecal coliforms levels at the sampling points (Table 2, Figure 3) ranged from 10.33 $\mathrm{MPN} \mathrm{g}^{-1}$ (C) to $27.70 \mathrm{MPN} \mathrm{g}^{-1}$ (D), with a four-point mean of 17.2 $\mathrm{MPN} \mathrm{g}^{-1}$. Total soil coliforms levels at the same

Table 2 - Physicochemical and microbiological characteristics of soils from the Marau Central Cemetery

\begin{tabular}{|c|c|c|c|c|c|c|c|}
\hline \multirow{3}{*}{$\begin{array}{l}\text { Sample } \\
\text { Site }\end{array}$} & \multicolumn{4}{|c|}{ Physiochemical parameters } & \multicolumn{3}{|c|}{ Microbial populations } \\
\hline & \multirow{2}{*}{$\underset{\left(\mathrm{g} \mathrm{hg}^{-1}\right)}{\mathrm{OC}}$} & \multirow{2}{*}{$\begin{array}{l}\text { BOD } \\
\left(\mathrm{mg} \mathrm{L}^{-1}\right)\end{array}$} & \multirow{2}{*}{$\begin{array}{c}\text { COD } \\
\left(\mathrm{mg} \mathrm{L}^{-1}\right)\end{array}$} & \multirow[t]{2}{*}{$\mathrm{pH}$} & \multicolumn{2}{|c|}{$\begin{array}{l}\text { Coliforms } \\
\text { (MPN g } \text { g }^{-1} \text { ) }\end{array}$} & \multirow{2}{*}{$\begin{array}{l}\text { Heterotrophs } \\
\text { (CFU g-1) }\end{array}$} \\
\hline & & & & & Fecal & Total & \\
\hline A & 7.75 & 2.10 & 6.37 & 7.27 & 13.33 & 533 & 9,167 \\
\hline B & 7.55 & 2.03 & 6.03 & 6.63 & 17.33 & 1,600 & 5,100 \\
\hline c & 7.41 & 11.03 & 3.33 & 6.20 & 10.33 & 500 & 2,933 \\
\hline D & 7.42 & 2.13 & 6.10 & 6.53 & 27.70 & 567 & 18,000 \\
\hline Avg. & 7.53 & 1.32 & 5.46 & 6.66 & 17.17 & 800 & 8,800 \\
\hline Tolerated limit & - & 5.00 & - & - & 2.10 & 500 & 500 \\
\hline
\end{tabular}

Source: Results of analysis collected in the field by the authors (2015). 


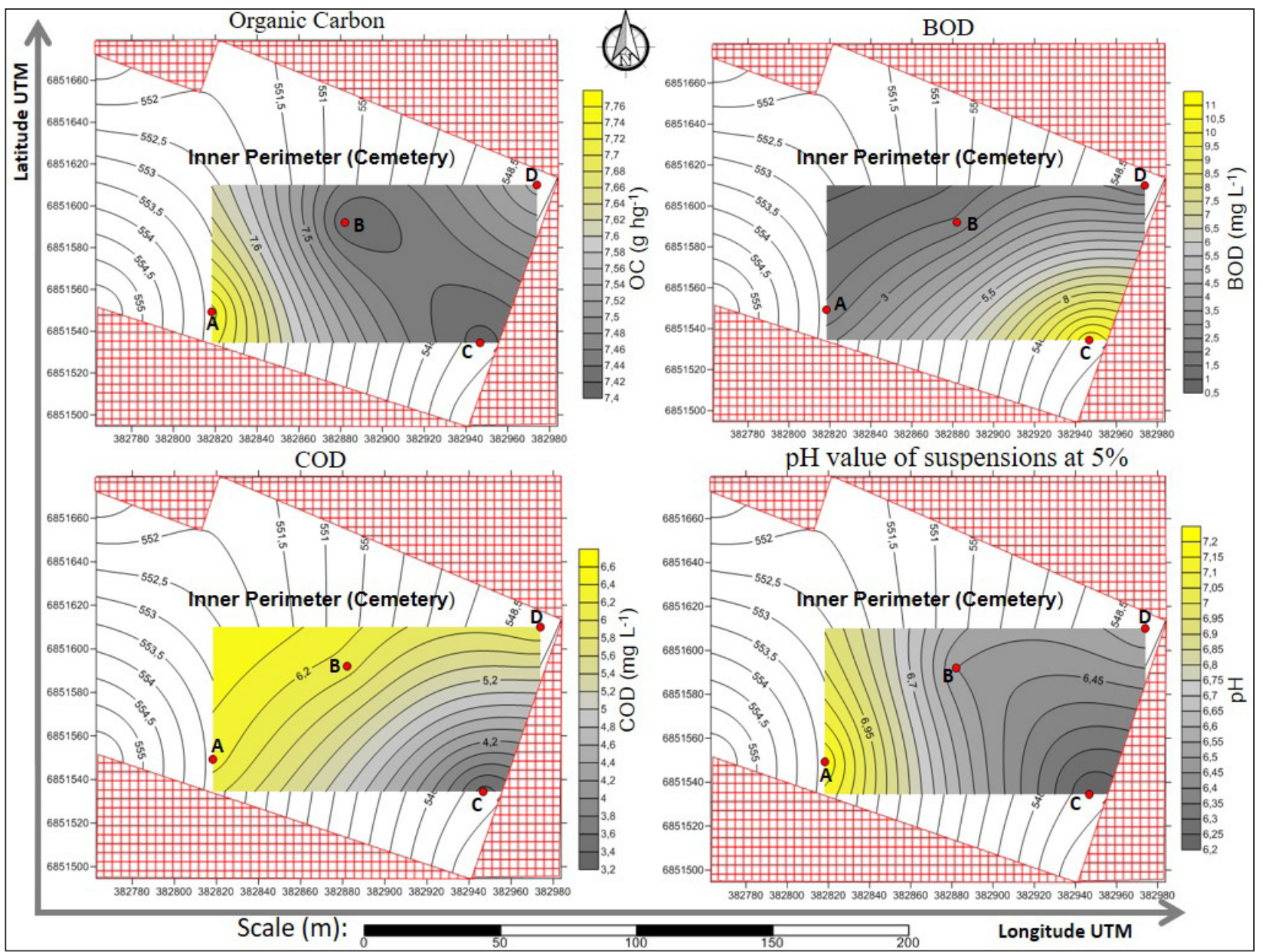

Figure 2 - Physical and Chemical Analyses in the sampled points (A, B, C, and D)

Source: The test results collected in the field by the authors modeled any surfer software (2016).

sampling points (Table 1, Figure 3) ranged from $500 \mathrm{MPN} \mathrm{g}^{-1}$ (C) to $1600 \mathrm{MPN} \mathrm{g}^{-1}$ (B), with an overall average of $800 \mathrm{MPN} \mathrm{g}^{-1}$. As the maximum allowable fecal and total coliform levels are $2.10 \mathrm{MPN} \mathrm{g}^{-1}$ and $500 \mathrm{MPN} \mathrm{g}^{-1}$, respectively (Rodrigues et al., 2013), the cemetery can be categorized as a highly unhealthy environment, likely to lead to contamination of the nearby population (Silva et al., 2008; Kim \& Kim, 2012; Rodrigues et al., 2013; Daynes et al., 2013). The high total coliform level at site $B$ is of concern because the point is located in the centre of the cemetery, and its topographic features are relatively low (Figure 4).

Soil heterotrophic bacteria counts at the sampling points (Table 2, Figure 3) ranged from $2933 \mathrm{CFU} \mathrm{mL}^{-1}$ (C) to $18000 \mathrm{CFU} \mathrm{mL}^{-1}$ (D), well above the acceptable upper limit of $500 \mathrm{CFU} \mathrm{mL}^{-1}$ (Silva, 2012). Silva (2012) stated that the heterotrophic bacteria found in cemeteries were the primary cause of pollution by organic matter in cemetery soil and groundwater aquifers. This organic pollutant or necroleachate had a viscous appearance, greyish colour, and was made up of $60 \%$ water, $30 \%$ mineral salts and $10 \%$ degradable organic substances. This material could transport putrescine and cadaverine through the soil (Leite, 2009; Kemerich et al., 2014). The highly toxic necroleachate can easily infiltrate and contaminate soil and groundwater and it is capable of proliferating infectious disease vectors such as bacteria of the genus Clostridium (tetanus, gas gangrene, toxic-infection of foods), Mycobacterium (tuberculosis), Salmonella typhi (typhoid fever), Salmonella paratyphi (paratyphoid fever), Shigella (bacillary dysentery) and the hepatitis A virus (Leite, 2009; Pereira et al., 2014; Kemerich et al., 2014; Pretti, 2015). In this case, the population living near Marau's Central Cemetery is susceptible to infections transmitted by these microorganisms. 


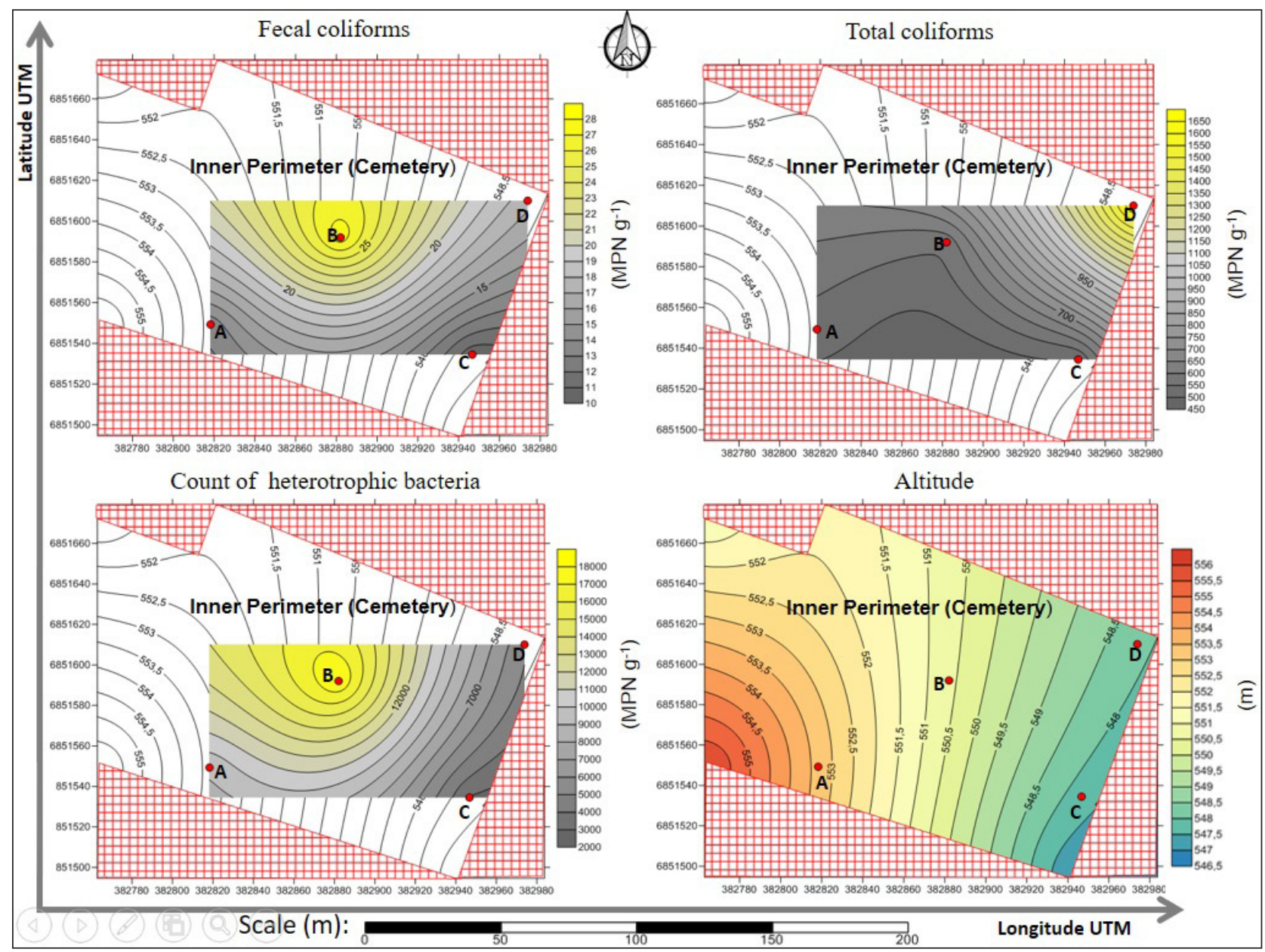

Figure 3 - Microbiological analyses for the sampled points (A, B, C and D)

Source: The test results collected in the field by the authors modeled any surfer software (2016).

According to Pereira et al. (2014) and Pretti (2015), this unhealthy situation for human populations is prevalent in a radius of up to $400 \mathrm{~m}$ beyond the cemetery boundaries.

This study showed high levels of microorganisms - especially fecal and total coliforms, but also heterotrophic bacteria contaminating the soil of a large urban cemetery in Marau (RS) Brazil. These findings concur with those of Yeung \& Han (2014), who assessed the presence of Escherichia coli as an indicator of fecal microbiological contamination in soil and found high levels of these organisms in Kowloon, Hong Kong, China. Ueda et al. (2011) found the main soil contaminants of a cemetery soil to be Grampositive bacilli, fungi, enterobacteriaceae, non-glucose fermenting Gram-negative bacilli, as well as other microorganisms. The quantification of these agents is widely used as an indicator of pre-sanitizing pollution, and post-sanitizing/post-processing contamination. Detection of these organisms above threshold levels indicates that hygienic practices and sanitation are below required standards (Rompré et al., 2002).

\section{The ideal cemetery}

In the past, the construction of cemeteries did not usually consider cremation, embalming or other modes of disposal of the dead. Even when the body is cremated, it needs to have a destination. Furthermore, any study of cemetery design must respect a wide range of religious or cultural beliefs. Therefore, cemetery design must consider the worsening environmental problems associated with cemeteries on both, local and global scale (Palma \& Silveira, 2011). In order to seek strategies to improve the quality of public 


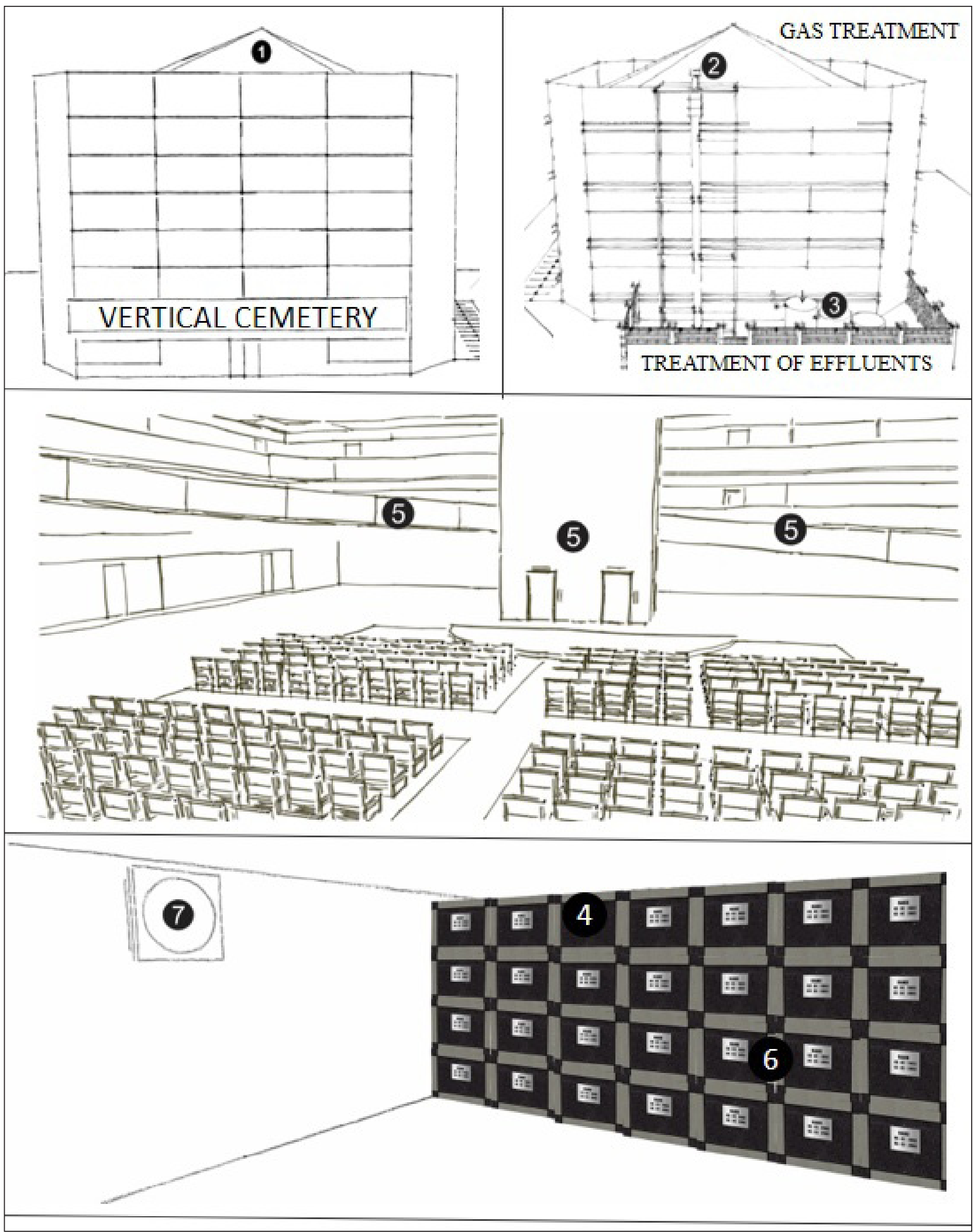

Figure 4 - Suggestions of urban planning given by professionals interviewed regarding the design of an ideal cemetery. (1) Vertical Cemetery; (2) Gas treatment; (3) Treatment of liquids released by decomposition of bodies (processing system); (4) Plates to facilitate the identification of sconces; (5) Optional elevators and wide access ramps with adequate slope to transport coffins and people with and without physical disabilities; (6) Isolation of graves from the environment to prevent odours; (7) Exhaust and cooling system Source: Prepared by the authors of results of interviews (2016). 
health, it is important to know the extent of the impacts of cemeteries in urban areas. Based on such considerations, it is obvious that Marau's Central Cemetery represents a threat to the quality of life not only of local residents, but also of people who are exposed and subject to any kind of contamination.

The ideal cemetery should treat the pollutants generated in the natural process of human body decomposition that occurs after death (Oliveira et al., 2012; Pereira et al., 2014; Pretti, 2015). Seeking to circumscribe these views, data was extracted from questionnaires answered by the 80 surveyed researchers, and was then categorized through Content Analysis Method (CAM). This method enabled the tabulation of quantitative and qualitative data, by using the categorization of statements attributed by respondents through the most repeated seven (7) responses, namely: (i) vertical cemetery, (ii) gas treatment, (iii) treatment of liquids released from decomposition of bodies (processing systems), (iv) plates to facilitate the identification of sconces, (v) wide access ramps with a suitable slope in order to facilitate the transport of coffins and the movement of people with and without disabilities, as well as optional elevators, (vi) isolation between tombs and the environment to prevent odours, (vii) exhaust and cooling systems (Figure 4).

All respondents felt that the appropriate type of cemetery to meet environmental sustainability standards should be vertical [(1) in Figure 4]. Albertin et al. (2013) defined a vertical cemetery as "[...] a building composed of one or more floors provided with compartments intended for burial, termed loci. This typology of cemeteries is a trend in the United States, Europe and Japan".

The construction of vertical cemeteries has been expanding in Brazil as they contribute to the efficient use of space, allows gas treatment, and avoids the necroleachate reach the environment. However, the limited number of vertical cemeteries in Brazil is reason of concern: only 17 vertical cemeteries were recensed in Brazil in 2013, of which 95\% were privately run, while the remainder were managed by municipal governments (Albertin et al., 2013).

Some $81 \%$ of the respondents indicated the need for the existence of facilities to treat gasses released by human bodies in decomposition. The gases released from decaying bodies need to be controlled and neutralized as they present a high contamination risk, given their association with the presence of necroleachate (Swann et al., 2010; Schotsmans et al., 2014). Neutralization of gases requires the installation of activated carbon filters on a system of pipes connected to each sconce, as established by Brazilian standards (Brasil, 2003).

Only $58 \%$ of respondents highlighted the importance of introducing the treatment of liquids released from decomposing bodies in vertical cemeteries. According to Albertin et al. (2013), the $60 \%$ aqueous solution created by putrefaction (necroleachate) and further composed of $30 \%$ minerals and $10 \%$ unpleasant organic substances, if untreated, can reach the environment and cause soil pollution. This can be avoided by the use of activated carbon filters (Oliveira et al., 2012; Schotsmans et al., 2014).

Some $20 \%$ of respondents suggested the inclusion of plates to facilitate the identification of sconces. The importance of road signs as a form of guidance is highlighted by Miura et al. (2015) as a form to reduce stress and worry of those attending or otherwise involved in burial services.

Some $15 \%$ of respondents suggested the introduction of optional elevators, wide access rampswith adequate slope to facilitate the transport of coffins and the movement of people with and without disabilities. Indeed, improvements to access would especially benefit people in wheelchairs (Ginsburg \& Rapp, 2013). According to Roulstone \& Prideaux (2009), the lesser the ramps' incline, the more they enable an easy access to the cemetery premises.

The survey also revealed that $12 \%$ of respondents suggested the isolation of graves to prevent odours, while $5 \%$ of respondents also suggested the introduction of an exhaust and cooling system to provide comfort to visitors and to minimize the door of flowers.

It is very important to prevent odours at locations such as cemeteries because besides the fact that released gases are highly toxic in their own right, they also carry pathogenic microorganisms (Kemerich et al., 2014; Trindade \& Neckel, 2014; Pretti, 2015). Furthermore, odours stemming from different species of flowers which are concentrated in one place can cause allergic reactions to those visiting the vertical cemetery. According to Trindade \& Neckel (2014) and Pretti (2015), the solution would be to introduce extraction fans that would be responsible for the circulation of air in the room, and would function as a catalyst. 
The synthesis of the views of 80 respondents on what would be an ideal cemetery, that is, one that includes the essential elements of vertical cemeteries in ideal scenarios, is presented in Figure 4.

When designing a vertical cemetery, what should be taken into account are the health benefits for the population and environment, not just the costs invested in construction (Brown, 2013; Trindade \& Neckel, 2014; Pretti, 2015). Therefore, vertical cemeteries would be integrated to urban growth, without causing risks of contamination for the population living near these cemeteries (Lauwers, 2015).

\section{Conclusions}

Based on the data collected, there is a predominance of open graves, along the lines of landfills, in the cemeteries of Marau Township, RS, Brazil. As a result of storing significant amounts of contaminating materials, without any preventive structures to avoid contamination of soil, groundwater and surface water, these improperly managed cemetery sites pose a major environmental threat.

The great risk of percolation of contaminants to ground water can be assessed through intensive monitoring with piezometers. Another factor that stands out is the lack of care of cemetery goers and managers who abandon vases and ornaments that do not receive proper disposal, and then accumulate rainwater. This causes an imbalance in the environment due to the creation and proliferation of vectors. This brings problems for the population, such as the emergence of diseases and even epidemics, and hinders the work of health surveillance teams which cannot constantly monitor the 44 cemeteries within Marau township.

The various burial sites must receive greater care, as many were found open at the time of the survey. This exposes further negative factors in terms of aesthetics and general issues of sanitation. Afforestation is another point of embellishment that should be studied. Some native species of trees could be planted in the cemetery, as long as they are approved by a responsible qualified technician.

The amount of physical, chemical and organic agents percolating through the soil of the Central Cemetery undoubtedly causes contamination, despite the absence of hard evidence. Likewise, there is no data regarding radioactive contamination of the soil, even in small quantities. This could be an issue in the case of people who died soon after receiving radiotherapy sessions or who had a pacemaker.

Microbiological tests performed in the Central Cemetery diagnosed the presence of fecal and total coliforms as well as heterotrophic bacteria above the acceptable levels. The spread of these agents could endanger the health of people living close to this cemetery.

Respondents showed great interest in responding the questions because, according to them, it was something necessary. Therefore, not only in the city of Marau, but in relation to the global context, there is a need to plan vertical cemeteries because trends indicate that cemeteries are already full and unable to house new corpses.

The 80 professionals from different countries and areas of expertise (urban planning, architects and environmental researchers) interviewed in this study were unanimous in suggesting vertical cemeteries as the option to minimize potential pollution to the environment. This would also be the most appropriate method for burials, because it would allow the treatment of substances generated by the human body during decomposition.

The results of this study also suggest the need to prepare Cemetery Management Plans, allowing the proper disposal of bodies in the environment and promoting the adoption of different forms of necroleachate treatment to prevent environmental risks that cemeteries can pose to the population. However, the idea is not to rid ourselves of what was done in the past, because there are cemeteries where members of the same family have been buried for generations, but to find ways to force these old cemeteries to meet licensing criteria to continue to operate.

Another issue to be considered in this study is that it is important that urban planning take into account the contamination that cemeteries cause on cities. This issue enables planners to rethink new solutions and to inform the population about the existing risks of living close to cemeteries.

\section{References}

Albertin, R. M., Mondini, J. M., Porto, V. O. P., Angeoletto, F., Silva, F. F., \& Angelis, B. L. D. (2013). Environmental 
impact analysis and identification of vertical cemetery implantation and operation.Agro@mbiente On-line, 7(1), 112-118. http://dx.doi.org/10.18227/1982-8470ragro. v7i1.894.

Alnsour, J. A. (2016). Managing urban growth in the city of Amman, Jordan. Cities, 50(2), 93-99. http://dx.doi. org/10.1016/j.cities.2015.08.011.

American Public Health Association - APHA. American Water Works Association - AWWA. Water Environment Federation - WEF. (2005). Standard methods for the examination of water and wastewater (21th ed., Vol. 1). Washington.

Bardin, L. (2011). Análise de conteúdo (3th ed. Vol. 1). São Paulo: Edições 70.

Bennett, G., \& Davies, P. J. (2015). Urban cemetery planning and the conflicting role of local and regional interests. Land Use Policy, 42(1), 450-459. http://dx.doi.org/10.1016/j. landusepol.2014.08.011.

Brasil. Conselho Nacional do Meio Ambiente - CONAMA. (2003). Resolução do Conama no 335, de 3 de abril de 2003. Brasília: Diário Oficial da União. Retrieved in 29 August 2015, from http://www.mma.gov.br/port/conama/res/ res03/res33503.xml

Brasil. Conselho Nacional do Meio Ambiente - CONAMA. (2008). Resolução do Conama n⿳o 402, de 17 de novembro de 2008. Brasília: Diário Oficial da União. Retrieved in 26 August 2015, from http://www.mma.gov.br/port/conama/ legiabre.cfm?codlegi $=590$

Brown, T. (2013). The making of urban 'healtheries': the transformation of cemeteries and burial grounds in lateVictorian East London. Journal of Historical Geography, 42(100), 12-23. PMid:24882920. http://dx.doi.org/10.1016/j. jhg.2013.05.001.

Całkosiński, I., Płoneczka-Janeczko, K., Ostapska, M., Dudek, K., Gamian, A., \& Rypuła, K. (2015). Microbiological analysis of necrosols collected from urban cemeteries in Poland. BioMed Research International, 1(1), 1-7. PMid:26301242. http://dx.doi.org/10.1155/2015/169573.

Colantoni, A., Grigoriadis, E., Sateriano, A., Venanzoni, G., \& Salvati, L. (2016). Cities as selective land predators? A lesson on urban growth, deregulated planning and sprawl containment. The Science of the Total Environment, 545-546 (1),329-339. PMid:26747997. http://dx.doi.org/10.1016/j. scitotenv.2015.11.170.
Curşeu, P. L., \& Pop-Curşeu, I. (2011). Alive after death: an exploratory cultural artifact analysis of the merry cemetery of Sapanta. Journal of Community \& Applied Social Psychology, 21(5), 371-387. http://dx.doi.org/10.1002/casp.1080.

Daynes, C. N., Field, D. J., Saleeba, J. A., Cole, M. A., \& McGee, P. A. (2013). Development and stabilisation of soil structure via interactions between organic matter, arbuscular mycorrhizal fungi and plant roots. Soil Biology \& Biochemistry, 57, 683-694. http://dx.doi.org/10.1016/j. soilbio.2012.09.020.

Dimakis, N. (2015). Ancient Greek deathscapes. Journal of Eastern Mediterranean Archaeology and Heritage Studies, 3(1), 27-41. http://dx.doi.org/10.5325/jeasmedarcherstu.3.1.0027.

Empresa Brasileira de Pesquisa Agropecuária - EMBRAPA. (2011). Fertilidade do solo: procedimento para coleta de amostras (pp. 30-81, Vol. 1, No. 1). Pelotas: Laboratório de Fertilidade do Solo, Embrapa Clima Temperado.

Fiorin, J. E. (2007). Manejo e fertilidade do solo no sistema de plantio direto. Passo Fundo: Berthier.

Firkowski, H. (2002). Generalização Cartográfica de Grades Retangulares Regulares Baseada na Teoria Matemática da Comunicação (PhD Thesis). Departamento de Geociências, Universidade Federal do Paraná, Curitiba.

Geleta, S. B., Briand, C. H., Folkoff, M. E., \& Zaprowski, B. J. (2014). Cemeteries as Indicators of Post-Settlement Anthropogenic Soil Degradation on the Atlantic Coastal Plain. Human Ecology, 42(4), 625-635. http://dx.doi. org/10.1007/s10745-014-9665-5.

Ginsburg, F., \& Rapp, R. (2013). Entangled ethnography: Imagining a future for young adults with learning disabilities. Social Science \& Medicine, 99(1), 187-193. PMid:24355478. http://dx.doi.org/10.1016/j.socscimed.2013.11.015.

Golden Software. (2015). Surfer version 12: Surface Mapping System. Colorado: Golden Software. CD-ROM.

Goren, O., Gavrieli, I., Burg, A., \& Lazar, B. (2011). Cation exchange and $\mathrm{CaCO}_{3}$ dissolution during artificial recharge of effluent to a calcareous sandstone aquifer. Journal of Hydrology, 400(1-2), 165-175. http://dx.doi.org/10.1016/j. jhydrol.2011.01.041.

Instituto Brasileiro de Geografia e Estatística - IBGE. (2014). Dados demográficos 2014. Rio de Janeiro: IBGE. Retrieved on 29 August, 2015, from http://cidades.ibge. gov.br/xtras/home.php 
Iriarte, J., Copé, S. M., Fradley, M., Lockhart, J. J., \& Gillam, J. C. (2013). Sacred landscapes of the southern Brazilian highlands: Understanding southern proto-Jê mound and enclosure complexes. Journal of Anthropological Archaeology, 32(1), 74-96. http://dx.doi.org/10.1016/j.jaa.2012.10.003.

Jones, D. (2011). The city of the dead: The place of cultural identity and environmental sustainability in the AfricanAmerican cemetery. Landscape Journal, 30(2), 226-240. http://dx.doi.org/10.3368/lj.30.2.226.

Kemerich, P. D. C., Silva, J. L. S., Borba, W. F., Flores, C. E. B., Barros, G., Gerhardt, A. E., Rodrigues, A. C., Silva, R. F., Flores, B. A., \& Ucker, F. E. (2014). Concentrations of metals in soil for busy cemetery: use the technique of ray fluorescence spectrometry-energy dispersive $\mathrm{x}$ - EDXRF. Monografias Ambientais, 14(1), 2875-2889.

Killgrove, K., \& Montgomery, J. (2016). All roads lead to rome: exploring human migration to the eternal city through biochemistry of skeletons from two imperial-era cemeteries (1st-3rd c AD). PLoS One, 11(2), 1-30. PMid:26863610. http://dx.doi.org/10.1371/journal.pone.0147585.

Kim, H. S., \& Kim, K. (2012). Microbial and chemical contamination of groundwater around livestock mortality burial sites in Korea: a review. Geosciences Journal, 16(4), 479-489. http://dx.doi.org/10.1007/s12303-012-0036-1.

Klaver, E. (2015). The cemetery as public space: spoon river anthology and act 3 of our town. Genre, 48(1), 99-118.

Lauwers, M. (2015). The birth of the cemetery: sacred places and land of the dead in the medieval West (1st ed., Vol. 1). Campinas: EdUnicamp.

Legislative Reference Bureau - ILCS. (1951). Cemetery Care Act, III. Illinois: ILCS. Retrieved in 12 April 2016, from www.ilga.gov

Leite, E. B. (2009). Análise físico-química e bacteriológica da água de poços localizados próximo ao cemitério da comunidade de Santana, Ilha de Maré, Salvador, BA. Candombá, 5(2), 132-148.

Marcomini, L. P. (2012). Avaliação de Impacto Ambiental do Cemitério Jardim dos Lírios do Município de Bauru-SP (PhD Thesis). Departamento de Engenharia de Produção, Universidade Estadual Paulista "Júlio de Mesquita Filho", Bauru.

McGowan, G., \& Prangnell, J. (2015). A method for calculating soil pressure overlying human burials. Journal of Archaeological Science, 53(1), 12-18. http://dx.doi. org/10.1016/j.jas.2014.09.016.

Miura, K., Kato, M., Dote, K., Kagawa, E., Nakano, Y., Oda, N., \& Sasaki, S. (2015). Association of non-culprit plaque characteristics with transient slow flow phenomenon during percutaneous coronary intervention. International Journal of Cardiology, 181(1), 108-113. PMid:25497531. http://dx.doi.org/10.1016/j.ijcard.2014.11.218.

Oliveira, B., Quinteiro, P., Caetano, C., Nadais, H., Arroja, L., Silva, E. F., \& Matias, M. S. (2012). Burial grounds' impact on groundwater and public health: an overview. Water and Environment Journal, 27(1), 99-106. http://dx.doi. org/10.1111/j.1747-6593.2012.00330.x.

Pacheco, A. (2000). Cemitério e meio ambiente (Thesis). Instituto de Geociências, Universidade de São Paulo, São Paulo.

Palma, S. R., \& Silveira, D. D. (2011). A saudade ecologicamente correta: a educação ambiental e os problemas ambientais em cemitérios. Monografias Ambientais, 2(2), 262-274.

Pereira, F., Hara, R., Gonçalves, L., Franco, L., Curtolo, R., Alves, G., Severi-Aguiar, G., \& Marin-Morales, M. (2014). Genotoxic effects of diamine putrescine assessed by comet assay in Wistar rats. Toxicology Letters, 229(3), S114. http://dx.doi.org/10.1016/j.toxlet.2014.06.412.

Pretti, M. A. (2015). Cadaverina $\left(\mathrm{C}_{5} \mathrm{H}_{14} \mathrm{~N}_{2}\right)$ e Putrescina $\left(\mathrm{C}_{4} \mathrm{H}_{12} \mathrm{~N}_{2}\right)$. São Paulo: SBQ. Retrieved in 29 August 2015, from http://qnint.sbq.org.br/qni/popup_visualizarMolecula. php?id=yIEibWJ_JADHSv2psd5MNZ03bSvbp5qEk9j8z3bw J6w0glCRz2hI2pD8Cgv8r437AQeCUt5-OF_l-UqvXNaIOg

Quinn, C. P. (2015). Returning and reuse: diachronic perspectives on multi-component cemeteries and mortuary politics at Middle Neolithic and Early Bronze Age Tara, Ireland. Journal of Anthropological Archaeology, 37(4), 1-18. http://dx.doi.org/10.1016/j.jaa.2014.10.003.

Ribeiro, R. M. (2015). Demanda por montanhismo na Região Metropolitana de Curitiba: método do experimento de escolha (PhD Thesis). Departamento de Engenharia Florestal, Universidade Federal do Paraná, Paraná.

Rodrigues, F. B., Mizobutsi, E. H., Mizobutsi, G. P., Ribiero, R. C. F., \& Veloso, J. S. (2013). Microbiological analysis of the "Prata Anã" banana produced in northern Minas Gerais. Bioscience Journal, 29(4), 826-832.

Rompré, A., Servais, P., Baudart, J., de-Roubin, M. R., \& Laurent, P. (2002). Detection and enumeration of coliforms in drinking 
water: current methods and emerging approaches. Journal of Microbiological Methods, 49(1), 31-54. PMid:11777581. http://dx.doi.org/10.1016/S0167-7012(01)00351-7.

Roulstone, A., \& Prideaux, S. (2009). Constructing reasonableness: Environmental access policy for disabled wheelchair users in four European Union countries. ALTER. European Journal of Disability Research, 3(4), 360-377. http://dx.doi.org/10.1016/j.alter.2009.03.004.

Rubio, A., Bellocq, M. I., \& Vezzani, D. (2012). Community structure of artificial container-breeding flies (Insecta: Diptera) in relation to the urbanization level. Landscape and Urban Planning, 105(3), 288-295. http://dx.doi. org/10.1016/j.landurbplan.2012.01.009.

Salles, N. A., Fourcade, F., Geneste, F., Floner, D., \& Amrane, A. (2010). Relevance of an electrochemical process prior to a biological treatment for the removal of an organophosphorous pesticide, phosmet. Journal of Hazardous Materials, 181(13), 617-623. PMid:20538412. http://dx.doi.org/10.1016/j. jhazmat.2010.05.057.

Schotsmans, E. M. J., Denton, J., Fletcher, J. N., Janaway, R. C., \& Wilson, A. S. (2014). Short-term effects of hydrated lime and quicklime on the decay of human remains using pig cadavers as human body analogues: Laboratory experiments. Forensic Science International, 238(1), 142. e1-142.e10. PMid:24513401. http://dx.doi.org/10.1016/j. forsciint.2013.12.047.

Silva, F. C., Suguio, K., \& Pacheco, A. (2008). Preliminary environmental evaluation of the Itaquera cemetery, according to resolution CONAMA 335/2003 São Paulo municipality. Revista UnG: Geociências, 7(1), 31-47.

Silva, F. V. (2012). Avaliação da contaminação das águas subterrâneas por atividade cemiterial na cidade de Maceió $A L$ (PhD Thesis). Universidade Federal de Alagoas, Maceió.

Silva, R. W. C., \& Malagutti, W., Jr. (2010). Emprego do imageamento elétrico no estudo da contaminação por cemitérios. Geociências, 29(3), 343-354.

Simonetti, M. C. (2012). Boundaries and surrounding walls in Ferrara Urban Cemetery: Ferdinando Canonici designs between architecture and town (1819-1873). Ricerche e
Progetti per il Territorio, la Città e L'architettura, 3(4), 203-226.

Stutter, M. I., Richards, S., \& Dawson, J. J. C. (2013). Biodegradability of natural dissolved organic matter collected from a UK moorland stream. Water Research, 47(3), 1169-1180. PMid:23261070. http://dx.doi.org/10.1016/j. watres.2012.11.035.

Swann, L. M., Forbes, S. L., \& Lewis, S. W. (2010). Analytical separations of mammalian decomposition products for forensic science: A review. Analytica Chimica Acta, 682(12), 9-22. PMid:21056711. http://dx.doi.org/10.1016/j. aca.2010.09.052.

Tournassat, C., Bizi, M., Braibant, G., \& Crouzet, C. (2011). Influence of montmorillonite tactoid size on $\mathrm{Na}-\mathrm{Ca}$ cation exchange reactions. Journal of Colloid and Interface Science, 364(2), 443-454. PMid:21920529. http://dx.doi. org/10.1016/j.jcis.2011.07.039.

Trindade, F. R., \& Neckel, A. (2014). Meio ambiente $e$ cemitérios (2nd ed., Vol. 1). Passo Fundo: Goellner.

Ueda, S. M., Silva, C. B., Miranda, M. A. L., Murça, M. A. S., Muñoz, D. R., Faria, M. L., Vita, R. F., \& Mimica, L. M. J. (2011). Comparação entre a microbiota da terra nos cemitérios: locais virgens e locais onde são enterrados corpos. Revista Arquivos Médicos dos Hospitais e da Faculdade de Ciências Médicas, 56(2), 74-79.

Yeung, K. L., \& Han, W. (2014). Zeolites and mesoporous materials in fuel cell applications. Catalysis Today, 236(2), 182-205. http://dx.doi.org/10.1016/j.cattod.2013.10.022.

Zhang, H., Merrett, D. C., Jing, Z., Tang, J., He, Y., Yue, H., Yue, Z., \& Yang, D. Y. (2016). Osteoarchaeological studies of human systemic stress of early urbanization in Late Shang at Anyang, China. PLoS One, 11(4), 1-25. PMid:27050400. http://dx.doi.org/10.1371/journal.pone.0151854.

Żychowski, J. (2012). Impact of cemeteries on groundwater chemistry: a review. Catena, 93(3), 29-37. http://dx.doi. org/10.1016/j.catena.2012.01.009.

Received: Nov. 17, 2015

Approved: May 17, 2016 